\title{
Local Social Capital for Community Empowerment Poor Rural (PNPM-MD) in Kalumpang District Mamuju Regency
}

\author{
Umi Farida $^{1}$ \\ \{umi_farida@stieamkop.ac.id ${ }^{1}$ \} \\ STIE Amkop, Makassar, Indonesia ${ }^{1}$
}

\begin{abstract}
This research is to understand, map and encourage community empowerment programs (PNPM-MD) by making maximum use of social capital in the community. This type of research is descriptive qualitative which aims to obtain a clear picture of the strategy for empowering the rural poor through the use of local social capital in Kalumpang District, Mamuju Regency. The results showed that poverty alleviation in Kalumpang District was implemented through a series of stages called the PNPM Mandiri Rural (PNPM MD) cycle, starting from poverty reflection, self-help mapping, establishing a medium-term poverty reduction program plan. The characteristics of the social capital of the Kalumpang sub-district community have grown and developed long before the PNPM program was implemented. The characteristics of social capital include trust, established networks, established values and norms, participation and pro-active action. The existence of this social capital contributes positively to the existence of a poverty reduction program through PNPM-MD which emphasizes community participation in various activities.
\end{abstract}

Keywords: Poverty, social capital, community empowerment.

\section{Introduction}

This Kostov and Lingrad (2001) stated that rural development in the future requires a new approach. Strengthening social capital in rural development can be seen as a very important reform of the approach. If rural development is not accompanied by strengthening institutions and organizations (Tjondronegoro, 1977), most community participation in rural areas (Sajogyo, 1974), and people's economic empowerment (Mubyarto, 2002), then whatever rural development programs or projects run by the government, will be difficult. achieve the expected results.

Economic experts in developed countries believe that the key to strengthening social capital lies in developing a network of relationships between the components of trust, networks, and cooperation. However, this is considered to be relatively superficial and has not touched directly on the roots or essence of strengthening social capital itself. In the context of community empowerment, the core of social capital is cultural values. Strengthening social capital needs to be initiated by strengthening local cultural values. In addition to cultural values, elements of social capital that are considered important to be developed in empowering rural communities are the competence of human resources or human resources 
(human capital), strong social management and civil society organizations (civil society), a non-imbalanced social structure, strong local leadership. strong, strong moral and legal systems, and good governance.

The concept of social capital is one of the important components to support the human development model, because in this model humans are placed as an important subject that determines the direction of development. Participation and the capacity to organize themselves are important so that society can play a role in the human development model.

\subsection{Poverty}

Poverty is defined as the inability to meet the minimum standard of living (Kuncoro, 2000: 103). However, the problem is actually not that simple, because poverty cannot be measured only by physical conditions, but is multicomplex and multidimensional in nature, among others, relating to social welfare, access to resources, education, health and protection of law and political rights. Therefore, in identifying poverty at least two approaches are used, the first emphasizes the notion of subsistence, namely "subsistence proverty", while the second understands poverty in a relative sense, namely poverty as "relative deprivation" (Mas'oed; 1999: 136) .

The subsistence approach considers poverty as a matter of inability to obtain the level of income needed to meet basic needs for food, clothing and several other basic needs. In other words, subsistence poverty is really absolute poverty. A person is said to be absolutely poor if his income level is lower than the absolute poverty line, or the amount of his income is not sufficient to meet the minimum living needs as reflected by the absolute poverty line. Absolute poverty is generally juxtaposed with relative poverty. Relative poverty is a condition of comparison between income groups in society, namely between groups that may not be poor because they have an income level higher than the poverty line, and groups of people who are relatively richer (Kartasasmita, 1996: 235).

The process of poverty that occurs in society can be understood based on its causes, namely natural poverty and artificial (artificial) poverty. Natural or natural poverty arises from the scarcity of natural resources, such as barren land, absence of irrigation and scarcity of other infrastructure. Meanwhile, artificial poverty is mostly caused by the emergence of institutions that make community members unable to evenly control existing economic resources, facilities and facilities. This kind of poverty is also known as structural poverty, because equal access to economic resources is hindered by existing structures in society (Mas'oed; 1999: 138)..

Sumodiningrat (1998: 27) states that based on the causes, poverty can be divided into three definitions, namely natural poverty, structural poverty and cultural poverty. Natural poverty is a condition of being poor because they are originally poor, because they do not have adequate resources, both natural resources, human resources and other resources, so they cannot participate in development.

Structural poverty is rooted in unbalanced development results and results that have not been evenly distributed, which is characterized by unequal ownership of resources, unbalanced community capacity and inequality of opportunities in development, which causes imbalance in income gains and an unequal community structure. Meanwhile, cultural poverty refers to the attitude of a person or society that is caused by their lifestyle, life habits and culture, in which they already feel sufficient and do not feel deprived.

The criterion used by the Central Bureau of Statistics (BPS) to measure the poverty line is the minimum expenditure needed to meet daily needs. This minimum need for life is measured by spending on food equivalent to 2100 calories per capita per day plus expenses for non-food 
needs which include housing, various goods and services, clothing and durable goods. In 1993 the minimum expenditure figure as the absolute poverty line was set at an average of Rp. 27,905 per capita per month for urban areas and Rp. 18,244, - for rural areas (Kartasasmita; 1996:

235).

\subsection{Social Capital}

Francis Fukuyama (1995) illustrates social capital in trust, believe and vertrauen, which means that the importance of trust is rooted in cultural factors such as ethics and morals. Trust arises so that the community shares a set of moral values, as a way to create public expectations and honesty. He also stated that local associations and networks do have a positive impact on improving economic welfare and local development and play an important role in environmental management. James S, Colement (1998) asserts that social capital is a tool for understanding social action theoretically combining sociological and economic perspectives. This understanding is emphasized by Ismail Serageldin (1998) that social capital always involves society and makes society appear not only from market interactions and having economic value.

Ismail Serageldin provides a classification of social capital, including:

- Social capital in the form of long-lasting but unidirectional social interactions, such as teaching and commerce, while social interactions with reciprocal relationships such as social networks and associations.

- Social capital in the form of social interaction effects is more durable in unidirectional relationships such as trust, respect and imitation, while in the form of reciprocal relationships such as gossip, reputation, pooling, social roles and coordination, all of these contain high economic value.

\subsection{Community Empowerment}

The notion of empowerment can be understood through a human-centered development approach which aims to achieve community independence. The placement of the human aspect in this approach is the main focus and the main source of development, so that society is not only seen as the object of development but also the main subject or actor of development and the role of the government in this case as a facilitator that facilitates the growth of community initiative and independence. In this regard, Bookman and Morgen say that empowerment as a concept that is currently popular refers to an effort to foster a desire for someone to actualize oneself, perform upward mobility, and provide psychological experiences that make a person feel empowered (Hendytio and J Babari, 1996: 177 ). In the discussion on empowerment, several types of capital have been discussed, such as physical capital, natural capital, financial capital, human capital and social capital. All of this capital has an important role in empowerment, but as has been stated in the discussion on integrated community development, it is known that empowerment activities cannot always be carried out simultaneously. The series of empowerment activities needs to be carried out systematically and complement each other.

The purpose of empowerment must be interpreted as an effort to improve the capacity of society in all aspects. However, there are certain aspects that are considered to be strengthened first so that society can develop other aspects. From a review of the weakness of physical capital as an entry point for empowerment programs and an analysis of the negative impacts of economic capital assistance, the two types of capital are not appropriate to be used as basic capital in empowerment. Apart from these two types of capital, there is natural capital, human capital and social capital. Human capital and social capital are inseparable parts even though 
the resulting output is different. Human capital can be seen from the output in the form of knowledge, skills and ability to act. Social capital is a very abstract capital and its output can only be seen in the form of action-reaction between people.

In the context of empowerment, the explanation of social capital is very relevant to answer the question of who will do the empowerment, what is done and how they do it. Ife and Tesoriero (2008: 363) say that:

"All community development should aim at building society. Community development involves developing social capital, strengthening social interactions in society, bringing them together and helping them to communicate with each other in a way that can lead to genuine dialogue, understanding and social action "..

From Ife and Tesoriero's explanation regarding social capital in community development, it can be seen that social capital is capital that can be used as a driving force in empowerment. Social capital provides support for the community to take action collectively and in return. Apart from being a capital that can drive empowerment, social capital is also empowerment itself. According to Ife and Tesoriero (2008: 35) "part of building social capital is strengthening 'civil society'. Civil society is a term used for formal or semi-formal structures that people form voluntarily on their own initiative, not as a consequence of a specific program or direction from the government". To further understand the strengths that exist in social capital, a study of the notion of social capital, its dimensions and elements is intended to provide an overview of the importance of social capital in empowerment.

The National Program for Independent Rural Community Empowerment (PNPM MD) in Mamuju Regency began in 2007 which at that time was a change from the District Development Program (PPK) which was undergoing an introduction period or the Socialization phase in 2002. The National Independent Community Empowerment Program was directed to increase effectiveness poverty reduction and job creation by involving elements of the community from the planning, implementation, to monitoring and evaluation stages. Through a participatory development process, critical awareness and independence of the community, especially the poor, can be developed, so that they are not only objects but also subjects in poverty reduction efforts. The National Independent Community Empowerment Program fully adopts the mechanisms and procedures for the District Development Program (PPK) which have been successfully implemented so far. In KDP, there are several activities that are funded, such as the construction of physical facilities that have both short and long term impacts on improving the economy and the welfare of local communities. For example construction of roads, bridges, markets, village irrigation, power plants, and others.

The existence of the National Independent Rural Community Empowerment Program (PNPM MD) in Mamuju District, especially in Kalumpang District, has received support from various parties and provides great appreciation and hope. Given the condition of Kalumpang District, it is a reflection of the poor, whose lives are left behind, isolated and isolated compared to people in other areas in Mamuju Regency. Geographical situation that is difficult to reach because it is in a mountainous area and is located at the end of Mamuju Regency.

In this study, the focus of the study is to analyze the extent to which the use of social capital in community empowerment programs, especially in PNPM-MD in Kalumpang District, Mamuju Regency, by using the parameters of participation in social / work organization networks, mutual trust, and adherence to norms. 


\section{Method}

The research method used in this research is qualitative, using research instruments of interviews, questionnaires and focus group discussion (FGD).

The initial instrument of this research is to describe a number of indicators and parameters of Social Capital, namely:

1. Participation in social organization networks / work.

2. Trust between people,

3. Adherence to norms

The research location used in this study is in Kalumpang District, Mamuju Regency. The characteristics of the selected research locations were adjusted to the research objectives, namely the rural areas inhabited by the rural poor in Kalumpang District, as well as the implementation location for the PNPM-MD program in Mamuju Regency.

\section{Result and Discussions}

\subsection{Overview of Kalumpang District, Mamuju Regency.}

Mamuju Regency consists of 142 villages and 11 sub-districts, with a population of approximately 336,879, - people / 86,623 heads of families (KK). The livelihoods of most of the residents in this Regency are fishermen, farmers, farmers, plantations and civil and private servants. As many as $50 \%$ of the households in this district are classified as poor / poor households (RTM). The poorest village in the district is Sandapan Village, Kalumpang Subdistrict, with the number of poor households up to $85 \%$ and an average income of Rp. 15,000 per day. Most of the community $(80 \%)$ has a junior high school education (SLTP). While accumulatively, the poorest sub-district in this district is Kalumpang district.

\subsection{Social Capital in Community Empowerment Programs}

In general, the implementation of PNPM Mandiri in Kalumpang District has been going well, starting from the socialization process to the community, planning activities which include the exploration of ideas in each hamlet down to the village level, Inter-village deliberations at the District level, implementation of infrastructure development activities, maintenance processes. existing infrastructure, down to the factors that influence the implementation of public infrastructure development in Kalumpang District.

This section will describe in more detail how the use of social capital in the implementation of the National Program for Rural Community Empowerment (PNPM-MD) in Kalumpang District, as for the subject, namely:

\section{Participation in Social/ Work Organization Networks.}

This indicator can be seen from the willingness to build a network of cooperation among others, openness in social / work relationships or networks, activeness in conflict resolution, activeness in maintaining and developing social / work relationships or networks. Based on the results of interviews with the PNPM Mandiri District Facilitator, Mamuju Regency said: "The people in Kalumpang sub-district are very enthusiastic in building cooperation with village institutions in order to make the PNPM MD program in Kalumpang District a success. We, as facilitators of the empowerment program, are very grateful because the people here 
are very participatory and open, all of this is good for the success of the empowerment program in Kalumpang sub-district "(Interview Results, January 18 2018, 10:15 a.m. local time).

The results of the interview with the Secretary of Kalumpang District, Mamuju Regency said:

"The existence of the National Program for Independent Community Empowerment (PNPM Mandiri) in Kalumpang District has brought many significant changes, especially in improving the quality of community human resources. Specifically, it is hoped that the learning process of democratic politics for the community will occur. It is proven that the community is able to analyze, is able to express opinions, discuss, and supervise and control every activity that is carried out "plus 99\% of the people in Kalumpang District are happy with the presence of PNPM Mandiri in Kalumpang District because this Government Program has proven to prosper the community. (Interview Result: Secretary of Kalumpang District, 17 January 2018, 10.45 WIT)

From what the informants said above, it can be said that the benefits and strengthening of social capital, particularly in the form of participation in various activities in the National Independent Community Empowerment Program (PNPM Mandiri) in Kalumpang District, have shown encouraging results, which can be seen in the participation provided by community, especially in every activity organized by the PNPM Mandiri management, both from the sub-district and those in the village where they live, as quoted in the results of an interview with the Head of the Kalumpang District Inter-Village Cooperation Agency (BKAD) as follows:

"The PNPM Mandiri program is very helpful for the poor, especially in very remote areas in Kalumpang District, for example in the implementation of PLTHM (Turbine) electricity lighting and the construction of clean water sources, community participation, especially mothers through SPP funds" (Interview Results, Date 17 January 2018, 12.05 WIT.)

\section{Trust between Fellow}

One of the indicators of social capital in community empowerment programs is the level of trust in others, the level of trust in prevailing norms, the level of trust in community leaders, trust in government, trust in group leaders and other group administrators. From the results of monitoring and interviews with several informants and respondents. In general, respondents answered that they really believed in the community empowerment program that was being promoted by the government. Including the community believes in program administrators and also in the rules and norms that apply. This is reinforced by an explanation from one of the traditional leaders of the Kalumpang community, namely Mr. Eli, who stated that:

"We, the people of Kalumpang, are very grateful for the government for helping to empower the community through this PNPM MD program. Our region is quite isolated and there are still many poor people. We believe that this program will receive support from the community and will help prosper the Kalumpang community "(Interview Result, January 2018, 12:15 pm)

Community trust in community empowerment programs, PNPM-MD is increasing with the approach pattern of program implementers who approach the community directly, even living together with the community. Based on the results of an interview with one of the PNPM-MD facilitators, that:

"As facilitators, of course we have to provide a lot of assistance to the community, starting from developing what they have, living with them, and learning with them, so that what is the role of the community in implementing this program can be accommodated, so that later the community will have a sense of mutual cooperation. , Concern for the results of the program 
and prioritize the principle of benefits in implementing this program ". (Interview Results, January 19, 2018, at 1:00 p.m. local time)

\begin{abstract}
Adherence to norms
This social capital indicator can be seen in the level of compliance with adopted norms, the level of trust in the prevailing norms, the level of obedience to government regulations.

In village meetings, which are village community meetings as a means of socialization or dissemination of PNPM Mandiri Rural information, the decisions that are produced in intervillage deliberations are a statement of the capacity or willingness of the village to comply with and implement the provisions of PNPM Mandiri in Rural Areas, concepts and policies, planning activities with a pattern Initiating the Future of the Village (MMDD) as the basis for the preparation of the RPJMDes. During the meeting, the community agreed to obey and obey the rules and norms set out in PNPM-MD.

The results of interviews with community members Mr. Aris, who attended the PNPMMD Musdes stated that:

"We as citizens should obey and obey the rules of PNPM-MD, because we know all of this is for our common good, hopefully this program can help improve the welfare of the community here" (Interview Results, January 19 2018, 11.00 a.m. local time ).
\end{abstract}

\title{
4 Conclusion
}

The implementation of the PNPM Mandiri-based poverty reduction program in Kalumpang District, Mamuju Regency has been going well. The infrastructure facilities that have been built are felt to be very useful and help the people of Kalumpang District to live more properly.

In general, the villagers in Kalumpang sub-district have strong social capital. In rural communities that have relatively strong social capital, the level of community welfare tends to be high and the process of socio-economic transformation takes place faster. Several indicators of social capital in supporting the PNPM-MD program in a sustainable manner are strong or weak participation and solidarity, trust, adherence to the rules / norms that are the provisions of the local community empowerment program. Relatively sharp social capital can be clearly seen at the village community level.

The National Independent Rural Community Empowerment Program (PNPM MD) which was implemented in Kalumpang District did not experience so many problems because in terms of preparation and community participation in each activity process it was carried out jointly so that the results obtained could be maximized.

The development of a model for strengthening social capital requires a deep background understanding of strengthening values, small community-based community organization, sound social management, non-formal leadership, and good governance. Therefore, empowerment of rural communities through strengthening their social capital needs to be put in the frame of the transformation or development of rural communities in a sustainable manner.

\section{References}


[1] Akhmadi, Nuning (ed).,Sumarto, Sudarno et al. 2004. Tata Kelola Pemerintah dan Penaggulangan Kemiskinan. Makalah dari Lembaga Penelitian SMERU, dengan dukungan dari AusAID, the Ford Foundation, dan DFID

[2] Akhmadi. 2004. Perencanaan dan Penganggaran Strategi Penanggulangan Kemiskinan di Daerah: Kasus Sulawesi Selatan. Dalam Hariyanti Sadali dan Nuning Akhmadi (eds). "Perencanaan dan Penganggaran Strategi Penanggulangan Kemiskinan di Daerah: Pola Mana yang PalingTepat?” Prosiding Lokakarya, Makassar. Jakarta: Lembaga Penelitian SMERU

[3] Ali Wafa, Urgensi Keberadaan Social Capital dalam Kelompok-kelompok Sosial Masyarakat, hlm. 45

[4] Blaxall, John. 2000. Governance and Poverty. Makalah dipresentasikan pada The Joint Workshop on Poverty Reduction Strategies in Mongolia, the world Bank, Ulan Bator, Mongolia, October 4 to $6 . \quad$ Diambil dari http://www.worldbank.org/poverty/strategies/events/mongolia/gov.pdf

[5] Babari, J dan Onny S Prijino. 1996. Pendidikan Sebagai Sarana Pemberdayaan Hasil evaluasi pemanfaatan pekarangan (urban farming) bagi keluarga miskin kota Surabaya 2010: Pemerintah Kota Surabaya

[6] Coleman J. S. 1988. Social Capital in the Creation of Human Capital. American Journal of Sociology 94 (supplement): S95-S120.

[7] Dasgupta, Partha dan Serageldin, Ismail. (ed). 1998. Social Capital: Multifaceted Perspective. Washington D.C. - USA: The World Bank

[8] Espanaton, Joseph W. 1986. Institution Building and Development: From Concept to Application. Jakarta: IKIP.

[9] Harton, Paul B. \& Chester Hunt. 1991. Sociology. Western Michigan University

[10] Hikmat, Harry. 2010. Strategi Pemberdayaan Masyarakat. Bandung : Humaniora Utama Press. Huraerah, Abu. 2008. Pengorganisasian dan Pengembangan Masyarakat Model dan Strategi Pembangunan Berbasis Kerakyatan. Bandung:Humaniora. Laporan Pelaksanaan Kegiatan Pengembangan Perikanan

[11] Jim, Ife dan Frank Tesoriero. 2008. Community Development: Alternatif Pengembangan Masyarakat di Era Globalisasi, Yogyakarta, Pustaka Pelajar. Hal.363

[12] Kostov, P and J. Lingrad. 2001. Integrated Rural Development - Do We Need a New Approach?. 73rd Seminar on the European Association of Agricultural Economists, 28030 June 2001, ANCONA. http://nwu.fig.net/pub/morocco/ proceedings/TS4/TS4_3_gur_et_al.pdf. [07/04/2004]Lesser, E., 2000, Knowledge and Social Capital: Foundation and Application, Boston : Butterworth-Heinemann,

[13] Prijono, Onny S. 1966. Pemberdayaan Konsep, Kebjakan dan Implementasi. Jakarta: Centre for Strategic and International Studies.

[14] Pedoman umum, Program Nasional Pemberdayaan Masyarakat Mandiri (PNPM MANDIRI) oleh Tim pengendali PNPM Mandiri, 2007/2008

[15] Buku Pedoman, Mamuju Dalam Angka, sekretariat Daerah Kabupaten Mamuju

[16] Buku Pedoman, Kalumpang Dalam Angka, sekretariat Daerah Kabupaten Mamuju

[17] Peraturan Pemerintah Nomor 72 Tahun 2005 tentang Pemerintah Desa.

[18] Peraturan Pemerintah Nomor 73 Tahun 2005 tentang Kelurahan.

[19] Peraturan Presiden Nomor 54 Tahun 2005 tentang Tim Koordinasi Penanggulangan Kemiskinan.

[20] Undang-Undang Nomor 25 Tahun 2004 tentang Sistem Perencanaan Pembangunan Nasional (SPPN). 
[21] Undang-Undang No. 17 Tahun 2007 tentang Rencana Pembangunan Jangka Panjang Nasional 2005-2025.

[22] Peraturan Presiden Nomor. 7 Tahun 2005 tentang Rencana Pembangunan Jangka Menengah (RPJM) Nasional 2004-2009.

[23] Keputusan Menteri Koordinator Bidang Kesejahteraan Rakyat selaku Ketua Tim Koordinasi Penanggulangan Kemiskinan Nomor 28/KEP/MENKO/KESRA/XI/ 2006 Tentang Tim Pengendali Program Nasional Pemberdayaan Masyarakat.

[24] Laporan Akhir Pemb. Sarana Prasarana, TPK. Desa Kalumpang.

[25] Laporan Akhir Pemb. Sarana Prasarana, TPK. Desa Tumonga.

[26] Laporan Akhir Pemb. Sarana Prasarana, TPK. Desa Karama 